\title{
Improvement and Evaluation of Slide Irrigation Design in the Northern Delta Clay Soils
}

\author{
R. M. Khalifa ${ }^{1 *}$, M. M. Saied ${ }^{2}$ and M. R. Khalifa ${ }^{3}$ \\ ${ }^{1}$ Soils Dept. Faculty of Agriculture Damietta University, Egypt \\ ${ }^{2}$ Soils, Water and Environment Res. Inst., Agric. Res. Center, Egypt \\ ${ }^{3}$ Soil and Water Dept. Faculty of Agriculture, Kafrelsheikh University, Egypt
}

\begin{abstract}
A FIELD study was conducted in clay soil at Sakha farm, Kafr EL-Sheikh governorate in 2013/2014 and 2014/2015 growing seasons. The objective of this work is to evaluate the effect of level border irrigation system using ( $100 \mathrm{~m}$ length and $7 \mathrm{~m}$ width and $0.1 \%$ slope $)$ under different irrigation water discharge $\left(2.5,3.5\right.$ and $\left.4 \mathrm{~L} \mathrm{sec}^{-1} \mathrm{~m}^{-1}\right)$ and cut-off irrigation $(100,90$ and $85 \%$ of border length) on the infiltration characteristics, intake family and some irrigation parameters under post irrigation of wheat crop. The most important results include that, the irrigation at $4 \mathrm{~L} / \mathrm{sec} . / \mathrm{m}$ greatly affected the basic infiltration rate and cumulative infiltrated depth. Intake rates were decreased under water discharge and cut-off irrigation conditions in both seasons. The irrigation discharge at $4 \mathrm{~L} / \mathrm{sec} . / \mathrm{m}$ combined with cut-off at $85 \%$ of border length, the designed inflow time, deep percolation and run-off values were decreased, while water application efficiency was increased. The design ratio of inflow time to advance time is more than 2, meanwhile, the application time increased over the advance time, in this case the design is acceptable in clay soil. The measured irrigation stream was more than the design one, this caused increasing the amount of water applied. The design advance, recession and opportunity intake time were more than the measured one.It can be concluded that the design of border irrigation under different irrigation discharge and cut-off irrigation is reasonably efficient and values of different parameters fall within all the design limitations.
\end{abstract}

Keywords: Border design, Clay soil, Cut-off, Irrigation system, Irrigation discharge, Wheat crop..

\section{Introduction}

Surface irrigation is currently practiced on about $90 \%$ of the irrigated land in Egypt, generally at low levels of performance (e.g., poor application efficiency). Improper On-farm irrigation practices lead to poor water distribution, non-uniform growth, excessive leaching in some areas (leading to water logging), and insufficient leaching in others (leading to soil salinity buildup), all of which decrease the yield per unit of land area and per unit of water applied (Mohamedin et al. 2010, Aragues et al., 2011 and Pereira et al., 2012).Improvements in irrigation practices lead to more uniform water distribution, soil and water conservation (sustainability), and economic viability of irrigated agriculture. Thus, efficient On-farm irrigation methods are necessary for increasing crop production per unit of water applied (Strelkoff et al., 1999, Bautista et al., 2009, Morris et al., 2015 and Anwar et al., 2016).

Level system (border or furrow) irrigation is a method in which water is applied in sufficient quantity over a relatively short time period to level land areas, such that the entire area is quickly covered by gravity flow distribution. The level areas are surrounded by control barriers (dikes, bunds, etc.). The method is best suited for medium to low intake rate soils can be used for irrigating all crops. Proper design of level irrigation systems (basin dimensions, number of furrows which can be irrigated, etc.) depends on the water supply flow rate, soil infiltration characteristics and other factors (Amer, 2011, EL-Hadidi et al., 2016 and Salahu et al., 2018).

Surface runoff losses are eliminated, high application efficiency, $90 \%$ or greater, are

*Corresponding author:dr_ramykhalifa@yahoo.com

DOI :10.21608/ejss.2018.2632.1154

(C)2017 Nathional Information and Documentaion Center (NIDOC) 
possible. Deep percolation losses can be held to an acceptable level. Properly designed and managed border strips can apply irrigation water at high levels of efficiency and uniformity and with minimal adverse effects to the environment (Zerihunet al. 2005; Chen et al. 2012; Darouich et al. 2012; Qingfeng Miao et al. 2015) proper design of surface irrigation systems takes into account the soil type (texture and intake rate), slope levelness of the field, stream size, and length of run. The evaluation of any irrigation system necessarily requires the collection and analysis of a large amount of data. Not the least of which are basic preliminary site data which can be obtained. The purpose of evaluating irrigation systems is fourfold:

(a) To determine the efficiency of the system as it is being used;

(b) To determine how effectively the system can be operated and whether it can be improved;

(c) To obtain information that will assist engineers in designing other systems;

(d) Operating procedures as a basis for economic decisions.

Evaluations involve measuring conditions at one or more points in a field selected to be typical or representative. The objective of this research is to present and discuss farm irrigation system design improvements and evaluation for the experiment that conducted at Sakha farm, Kafr El-sheikh Governorate. These improvements are based on useful and easily applied design techniques. The improvements have three main emphases which include (1) precision land leveling to dead level,

(2) different irrigation water discharge and (3) different cut-off irrigation at different irrigation run lengths.

\section{Materials and Methods}

Location of the studied area

A field experiment was carried out during two winter seasons 2013/2014 and 2014/2015 at Sakha Agricultural Research Station which situated at $31^{\circ} 07 \mathrm{~N}$ latitude, $30^{\circ} 57-\mathrm{E}$ longitude. It has an elevation of about 6 meters above the sea level. It represents the conditions and circumstances of middle northern part of the Nile Delta region. The aim of this work is to present and discuss farm irrigation system design improvements and evaluation.

\section{Soil characteristics}

Disturbed and undisturbed soil samples were taken before sowing of wheat from 4 depths namely:0-15, 15-30, 30-45 and 45-60 $\mathrm{cm}$, respectively, air dried, grounded, sieved and prepared for physical and chemical analysis. Particle size distribution for soil was carried out using the pipette method, to obtain soil texture. Soil bulk densityand total porosity weremeasured using the core sampling technique as described by (Campbell, 1994). Infiltration rate (IR) $\mathrm{cm} \mathrm{hr}^{-1}$ : was determined by using double ring infiltrometer before planting, before post irrigation and after harvesting.Soil water constants i.e. field capacity (FC) and permanent wilting point (PWP) weredetermined by using pressure cooker method at 0.33 and 15 Atmosphere (Klute, 1986).

Soil reaction $\mathrm{pH}$ in soil suspension (1:2.5), EC and Soluble ions in soil paste extract were measured as mentioned by Page et al. (1982). Physical and chemical properties of the soil of the experimental fields are shown in Tables 1 and 2.

TABLE 1. Physical properties of the studied soil (mean values of 2 growing seasons)

\begin{tabular}{|c|c|c|c|c|c|c|c|c|c|c|}
\hline \multirow{2}{*}{$\begin{array}{c}\text { Soil } \\
\text { depth } \\
(\mathrm{cm})\end{array}$} & \multicolumn{3}{|c|}{$\begin{array}{c}\text { Particle size distribution } \\
(\%)\end{array}$} & \multirow{2}{*}{$\begin{array}{c}\text { Textural } \\
\text { class }\end{array}$} & \multirow{2}{*}{$\begin{array}{c}\text { Basic IR } \\
\text { (cm } \\
\text { hr-1) }\end{array}$} & \multirow{2}{*}{$\begin{array}{c}\text { Bulk } \\
\text { density } \\
\left(\mathrm{mg} \mathrm{m}^{-3}\right)\end{array}$} & \multirow{2}{*}{$\begin{array}{c}\text { Total } \\
\text { porosity } \\
(\%)\end{array}$} & \multicolumn{3}{|c|}{ Soil moisture constants } \\
\hline & Sand & Silt & Clay & & & & & $\begin{array}{l}\text { FC } \\
(\%)\end{array}$ & $\begin{array}{l}\text { PWP } \\
(\%)\end{array}$ & $\begin{array}{l}\text { Aw } \\
(\%)\end{array}$ \\
\hline $0-15$ & 17.19 & 27.66 & 55.15 & Clay & & 1.27 & 52.12 & 45.68 & 24.36 & 21.32 \\
\hline $15-30$ & 18.35 & 28.31 & 53.35 & Clay & & 1.36 & 48.70 & 44.19 & 22.98 & 21.21 \\
\hline $30-45$ & 18.49 & 29.41 & 52.10 & Clay & 0.87 & 1.37 & 48.38 & 39.42 & 21.42 & 18.0 \\
\hline $45-60$ & 20.21 & 30.29 & 49.50 & Clay & & 1.38 & 47.66 & 37.18 & 20.94 & 16.24 \\
\hline Mean & 18.56 & 28.92 & 52.53 & Clay & & 1.35 & 49.22 & 41.62 & 22.43 & 19.19 \\
\hline
\end{tabular}

IR: Infiltration rate, FC: Field capacity, PWP: Permanent wilting point, AW: Available water. 
TABLE 2. Chemical properties of the studied soil (mean values of 2 growing seasons)

\begin{tabular}{|c|c|c|c|c|c|c|c|c|c|c|c|}
\hline \multirow{2}{*}{$\begin{array}{c}\text { Soil } \\
\text { depth } \\
(\mathrm{cm})\end{array}$} & \multirow{2}{*}{$\begin{array}{c}\text { pH } \\
(1: 2.5) \\
\text { soil water } \\
\text { susp. }\end{array}$} & \multirow{2}{*}{$\begin{array}{c}\text { EC } \\
\left(\mathrm{dS} \mathrm{m}^{-1}\right) \\
\text { Soil } \\
\text { paste }\end{array}$} & \multirow[t]{2}{*}{ SAR } & \multicolumn{4}{|c|}{ Soluble cations (meq $\left.\mathbf{L}^{-1}\right)$} & \multicolumn{4}{|c|}{ Soluble anions (meq $\left.\mathrm{L}^{-1}\right)$} \\
\hline & & & & $\mathbf{N a}^{+}$ & $\mathbf{K}^{+}$ & $\mathbf{C a}^{++}$ & $\mathbf{M g}^{++}$ & $\mathrm{CO}_{3}^{--}$ & $\mathrm{HCO}_{3}^{-}$ & $\mathrm{Cl}^{-}$ & $\mathrm{SO}_{4}^{-}$ \\
\hline $0-15$ & 8.75 & 3.6 & 6.51 & 18.87 & 0.25 & 7.03 & 9.81 & - & 4.93 & 15.93 & 15.1 \\
\hline $15-30$ & 8.81 & 3.63 & 6.58 & 19.10 & 0.22 & 6.70 & 10.13 & - & 5.36 & 15.95 & 14.83 \\
\hline $30-45$ & 8.93 & 4.22 & 8.06 & 24.05 & 0.29 & 7.67 & 10.13 & - & 4.94 & 19.59 & 17.61 \\
\hline $45-60$ & 8.83 & 4.55 & 8.72 & 25.29 & 0.31 & 6.67 & 10.15 & - & 5.0 & 20.89 & 16.53 \\
\hline Mean & & 4.0 & 7.47 & 21.83 & 0.27 & 7.02 & 10.06 & - & 5.06 & 18.09 & 16.02 \\
\hline
\end{tabular}

\section{Experimental Layout}

The current investigation aimed to present and discuss farm irrigation system design improvements and evaluation of the different irrigation water discharge and cut-off irrigation at different percentages of border run length. The main plots were subjected to irrigation water discharge as follows :

D1: $2.5 \mathrm{~L} \mathrm{Sec}^{-1} \mathrm{~m}^{-1}$ width

D2: $3.5 \mathrm{~L} \mathrm{Sec}^{-1} \mathrm{~m}^{-1}$ width

D3: $4.0 \mathrm{~L} \mathrm{Sec}^{-1} \mathrm{~m}^{-1}$ width

The subplots were devoted to cut-off irrigation as follows :

C1: cut-off irrigation at $100 \%$ of border length

C2: cut-off irrigation at $90 \%$ of border length

C3: cut-off irrigation at $85 \%$ of border length

Border length was $100 \mathrm{~m}$ and $7 \mathrm{~m}$ widthand land leveling $0.1 \%$ slope was performed.

\section{Hydraulic relationships}

Designprocedures are based on those developed by the soil conservation service and apply the intake family concept. Graded border system design also applies the concept of discharge per unit width. The hydraulic relationships are derived by consideration of continuity relationships the manning equation, and the assumption that the amount volume of a section with a triangular cross-sectional shape as the recession curve moves down the field.Graded border systems are designed on the principle that any point in the field should have water applied to it for a time equal to that required to infiltrate the net depth of irrigation. In a graded border system, the time between cut-off of water at the head of the field and the disappearance of water at the head of the field is termed the recession lag time $\mathrm{T}_{\mathrm{t} 1}$.

The net time of infiltration, Tn is computed using an equation:

$\mathrm{Tn}=(\mathrm{in}-\mathrm{c} / \mathrm{a})^{1 / \mathrm{b}} \mathrm{in}=$ net irrigation depth $(\mathrm{mm})$ (Richard 1989)
It can be shown that the time to cut-off is equal to the net infiltration time minus the recession lag time

$$
\mathrm{Tco}=\mathrm{Tn}-\mathrm{T}_{\mathrm{t} 1}
$$

The term high gradient borders is used to denote borders with a surface slope greater than approximately $0.004 \mathrm{~m} / \mathrm{m}$. In such border, the water surface slope is assumed equal to the field slope and the normal flow depth-that is, the depth under conditions of uniform flow is assumed equal to the depth of flow at the head of flow the border. Under such conditions, the recession lag time is given by:

$$
\mathrm{T}_{\mathrm{t} 1}=(\mathrm{Qu})^{0.2}(\mathrm{n})^{1.2} / 120(\mathrm{~s})^{1.6}
$$

Where:

$$
\begin{aligned}
& \mathrm{T}_{\mathrm{t} 1}=\text { recession lag time, } \min \\
& \mathrm{Qu}=\text { unit inflow rate, } \mathrm{m}^{2} / \mathrm{s} \\
& \mathrm{n}=\text { Manning's roughness coefficient } \\
& \mathrm{s}=\text { surface slope, } \mathrm{m} / \mathrm{m}
\end{aligned}
$$

For low gradient borders with surface slopes of less than $0.004 \mathrm{~m} / \mathrm{m}$, the depth of flow at the head of the border is less than the normal depth hydraulic slope required in Manning's equation is no longer equal to the surface slope as in the case of uniform flow at normal depth. The hydraulic slope is approximated by the surface slope plus the depth of flow at the head of field divided by the length of advance. In such cases, the recession lag time is given by :

$$
\begin{gathered}
\mathrm{T}_{\mathrm{t} 1}=(\mathrm{Qu})^{0.2}(\mathrm{n})^{1.2} / 120\left(\mathrm{~s}+0.0094 \mathrm{n}(\mathrm{Qu})^{0.175} /\right. \\
\left.(\mathrm{Tn})^{0.88}(\mathrm{~s})^{0.5}\right)^{1.6}
\end{gathered}
$$

Where:

$\mathrm{Tn}=$ net infiltration time, $\min$

The unit inflow rate is derived from application of a balance between the volume of water applied to the border and the required net depth of irrigation divided by irrigation efficiency. 
The inflow rate per unit width of border strip in square meters per second is given by:

$$
\mathrm{Qu}=0.00167 \text { in } \mathrm{L} /\left(\mathrm{Tn}-\mathrm{T}_{\mathrm{t} 1}\right) \text { ed }
$$

Where:

$$
\begin{aligned}
& \text { in = net depth of irrigation, } \mathrm{mm} \\
& \mathrm{L}=\text { border length, } \mathrm{m} \\
& \text { ed = distribution pattern efficiency, percent }
\end{aligned}
$$

The maximum depth of flow in border strip is determined by the border ridge height. The border ridge height is normally established at 1.25 times the maximum flow depth. Maximum flow depths of less than $150 \mathrm{~mm}$ are generally acceptable. In certain soils resistant to erosion, flow depths in the range of $200 \mathrm{~mm}$ may be acceptable. The depth of flow at the head of the border in high gradient borders is the normal depth for uniform flow given by :

$$
\mathrm{dh}=1000(\mathrm{Qu})^{0.6}(\mathrm{n})^{0.6 / \mathrm{s}^{0.3}}
$$

where:

$$
\mathrm{dh}=\text { depth of flow at the head of border, } \mathrm{mm}
$$

For low gradient borders, flow is at a depth less than the normal depth which occurs under uniform flow. Under such conditions, dh may be calculated by :

$$
\mathrm{dh}=2454\left(\mathrm{~T}_{\mathrm{t} 1}\right)^{0.1875}(\mathrm{Qu})^{0.5625}(\mathrm{n})^{0.1875}
$$

\section{Design limitations}

The limitations are aimed at achieving reasonable efficiencies without excessive erosion based on the hydraulic considerations. Some of the limitations are empirical in nature while others are based on the hydraulic of flow. The final design should be checked to see that it falls within the constraints.

A maximum flow rate criterion has been established to aid in producing a design with a nonerosive stream size. For non-sodforming crops such as alfalfa and small grains, the stream size per unit width in square meters per second is given by :

$$
\mathrm{Qu}_{\max }=1.765 \times 10^{-4} / \mathrm{S}^{0.75}
$$

For well established, dense sod crops such as pasture and other grasses, the relationship is:

$$
\mathrm{Qu}_{\max }=3.53 \times 10^{-4} / \mathrm{S}^{0.75}
$$

A minimum depth of flow criterion is required to insure that the water stream is large enough to spread over the entire border. This minimum depth of flow is maintained by specifying a minimum

Egypt. J. Soil Sci., 58, No.2 (2018) unit inflow rate given by the following:

$$
\mathrm{Qu}_{\min }=5.95 \times 10^{-6} \mathrm{~L}(\mathrm{~S})^{0.5} / \mathrm{n}
$$

The maximum field slope is given as a function of surface roughness, net depth of irrigation, intake family, and desired irrigation efficiency. It is based on the principle of the minimum depth of flow. Normally, surface slopes of greater than $0.04 \mathrm{~m} / \mathrm{m}$ are not practical due to erosion hazards. The theoretical relationship for maximum slope is given by:

$$
\mathrm{S}_{\text {max }}=\left\{\mathrm{n} / 0.0117 \mathrm{ed} \times \text { in } / \mathrm{Tn}-\mathrm{T}_{\mathrm{t} 1}\right\}^{2}
$$

The maximum border length is limited by the maximum unit inflow rate. This rate is in turn limited by maximum nonerosive stream size on steeper borders and by maximum depth of flow on flatter borders. On borders of low field, slope made up of soils with low intake rates, the theoretical maximum may be too long for practical irrigation operations. Border lengths in excess of $400 \mathrm{~m}$ are generally considered excessive. The theoretical maximum length is given by :

$$
\mathrm{L}_{\max }=\mathrm{Qu}_{\max } \mathrm{ed}\left(\mathrm{T}_{\mathrm{n}-} \mathrm{T}_{\mathrm{t1}}\right) / 0.00167 \text { in }
$$

\section{Results and Discussion}

Intake characteristics of North Delta soils

Infiltration is generally defined as the process of water entry into the soil profile. The study and characterization of infiltration is of upmost important in irrigation. For design and evaluation purposes, it is necessary to know the rate at which water enters the soil and the amount which can be held in the profile before runoff and/or deep percolation begins. Soil infiltration capacities and rates are required data before irrigation designs or modifications can be formulated which will result in uniformly and efficiently applied water. This is especially true for surface irrigation methods. For border or basin irrigation, infiltration is generally assumed to occur vertically downward cone dimensional and affected by the shape of the infiltration surface affects the rate of water entry, as in furrow irrigation, this rate is more commonly termed intake rate. Most well drained soils will generally exhibit an initially high infiltration rate which decreases with time and eventually approaches a constant rate. This process of decreasing capillary pressure gradient resultedfrom a deepening wetting front. Several tests have been conducted to determine the range of infiltration characteristics of Sakha soils in the two growing seasons 2013/2014 and 2014/2015 as shown in Table 3 and illustrated in Fig. 1 and 2. 
TABLE 3. Basic infiltration rate $\left(\mathrm{cm} \mathrm{hr}^{-1}\right)$ and cumulative infiltrated depth for different treatments before post irrigation in the two growing seasons

\begin{tabular}{|c|c|c|c|c|c|}
\hline \multirow{2}{*}{$\begin{array}{c}\text { Irrigation } \\
\text { discharge } \\
\left(\mathrm{L} \mathrm{sec}^{-1} \mathbf{m}^{-1}\right)\end{array}$} & \multirow{2}{*}{$\begin{array}{l}\text { Elapsed time } \\
\text { (min) }\end{array}$} & \multicolumn{2}{|c|}{ Infiltration rate $\left(\mathrm{cmhr}^{-1}\right)$} & \multicolumn{2}{|c|}{ Cumulative infiltrated depth $(\mathrm{cm})$} \\
\hline & & $\begin{array}{l}1^{\text {st }} \text { season for all } \\
\text { cut-off irrigation }\end{array}$ & $\begin{array}{l}2^{\text {nd }} \text { season for all } \\
\text { cut-off irrigation }\end{array}$ & $1^{\text {st }}$ season & $\begin{array}{c}2^{\text {nd }} \\
\text { season }\end{array}$ \\
\hline \multirow[t]{10}{*}{2.5} & 5 & 8.88 & 9.12 & 0.74 & 0.76 \\
\hline & 10 & 4.92 & 5.04 & 1.15 & 1.18 \\
\hline & 20 & 2.4 & 2.46 & 1.55 & 1.59 \\
\hline & 30 & 1.5 & 1.62 & 1.8 & 1.86 \\
\hline & 45 & 1.0 & 1.04 & 2.05 & 2.12 \\
\hline & 60 & 2.0 & 2.04 & 2.55 & 2.63 \\
\hline & 90 & 1.10 & 1.12 & 3.10 & 3.19 \\
\hline & 120 & 1.14 & 1.18 & 3.67 & 3.78 \\
\hline & 180 & 0.89 & 0.9 & 4.56 & 4.68 \\
\hline & 240 & 0.89 & 0.9 & 5.45 & 5.58 \\
\hline \multirow[t]{10}{*}{3.5} & 5 & 9.6 & 9.72 & 0.8 & 0.81 \\
\hline & 10 & 5.28 & 5.4 & 1.24 & 1.26 \\
\hline & 20 & 3.36 & 3.42 & 1.8 & 1.83 \\
\hline & 30 & 1.68 & 1.8 & 2.08 & 2.13 \\
\hline & 45 & 1.76 & 1.84 & 2.52 & 2.59 \\
\hline & 60 & 2.16 & 2.24 & 3.06 & 3.15 \\
\hline & 90 & 1.04 & 1.08 & 3.58 & 3.69 \\
\hline & 120 & 1.08 & 1.12 & 4.12 & 4.25 \\
\hline & 180 & 0.92 & 0.93 & 5.04 & 5.18 \\
\hline & 240 & 0.92 & 0.93 & 5.96 & 6.11 \\
\hline \multirow[t]{10}{*}{4} & 5 & 9.84 & 10.1 & 0.82 & 0.84 \\
\hline & 10 & 5.52 & 5.76 & 1.28 & 1.32 \\
\hline & 20 & 3.48 & 3.6 & 1.86 & 1.92 \\
\hline & 30 & 1.8 & 1.92 & 2.16 & 2.24 \\
\hline & 45 & 1.84 & 1.92 & 2.62 & 2.72 \\
\hline & 60 & 2.24 & 2.32 & 3.18 & 3.30 \\
\hline & 90 & 1.04 & 1.08 & 3.7 & 3.84 \\
\hline & 120 & 1.06 & 1.10 & 4.23 & 4.39 \\
\hline & 180 & 0.93 & 0.94 & 5.16 & 5.33 \\
\hline & 240 & 0.93 & 0.94 & 6.09 & 6.27 \\
\hline
\end{tabular}

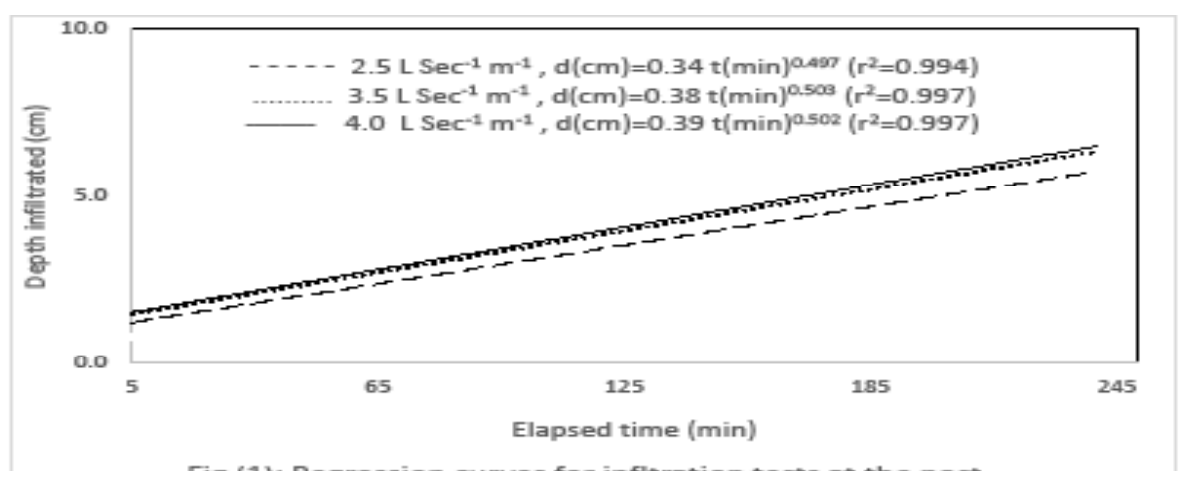

Fig.1. Regression curves for infltration tests at the post irrigation in the first season with different treatments 


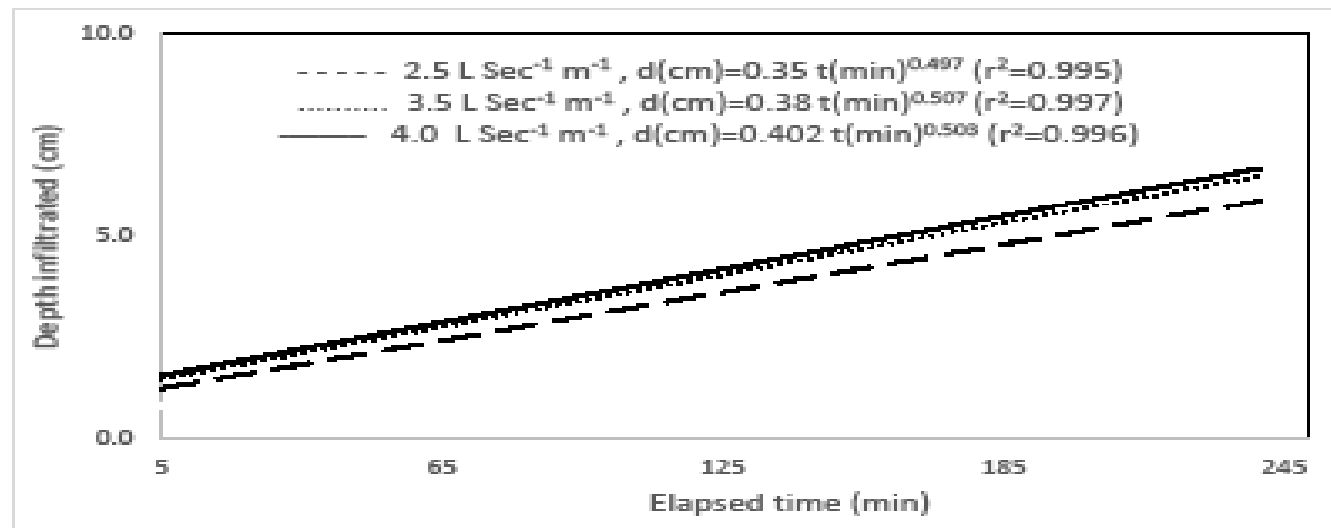

Fig.2. Regression curves for infltration tests at the post irrigation in the second season with different treatments

The rate at which a soil absorbs water usually decreases rather rapidly with time. After several hours however, it usually becomes nearly constant. This is called the basic infiltration rate (Garcia,1978).

Table 3 shows the infiltration rate and cumulative infiltration values as affected by different irrigation discharge and cut-off irrigation in 2013/2014 and 2014/2015 growing seasons.It was noticed that infiltration rates decreased rapidly from $8.88 \mathrm{~cm} \mathrm{hr}^{-1}$ to $0.89 \mathrm{~cm} \mathrm{hr}^{-1}$, from 9.6 to 0.92 $\mathrm{cm} \mathrm{hr}^{-1}$ and from 9.84 to $0.93 \mathrm{~cm} \mathrm{hr}^{-1}$ for $2.5,3.5$ and $4 \mathrm{~L} \mathrm{sec}^{-1} \mathrm{~m}^{-1}$ under all cut-off irrigation in the first season of study. While in the second season, the infiltration rates were decreased rapidly from 9.12 to $0.9 \mathrm{~cm} \mathrm{hr}^{-1}$, from 9.72 to $0.93 \mathrm{~cm} \mathrm{hr}^{-1}$ and from 10.1 to $0.94 \mathrm{~cm} \mathrm{hr}^{-1}$ for the stated treatments at 4 hours elapsed time.Generally, the irrigation at $4 \mathrm{~L} \mathrm{sec}^{-1} \mathrm{~m}^{-1}$ greatly affected the basic infiltration rate which the values of basic infiltration rate and cumulative infiltration values were increased compared to 2.5 and $3.5 \mathrm{~L} \mathrm{sec}^{-1} \mathrm{~m}^{-1}$ in both seasons of study.

\section{Infiltration function}

Table 4 shows the infiltration functions which the data obtained were reduced to the form of accumulated depth infiltrated in $(\mathrm{cm})$ vs. elapsed time in (minutes). These data were then subjected to a curve fitting regression to determine the best fit regression coefficients, in a power function of the form:

$$
\mathrm{Z}=\mathrm{a} \mathrm{T}^{\mathrm{b}}
$$

TABLE 4. Intake functions for the different treatments for post irrigation during the first and second seasons

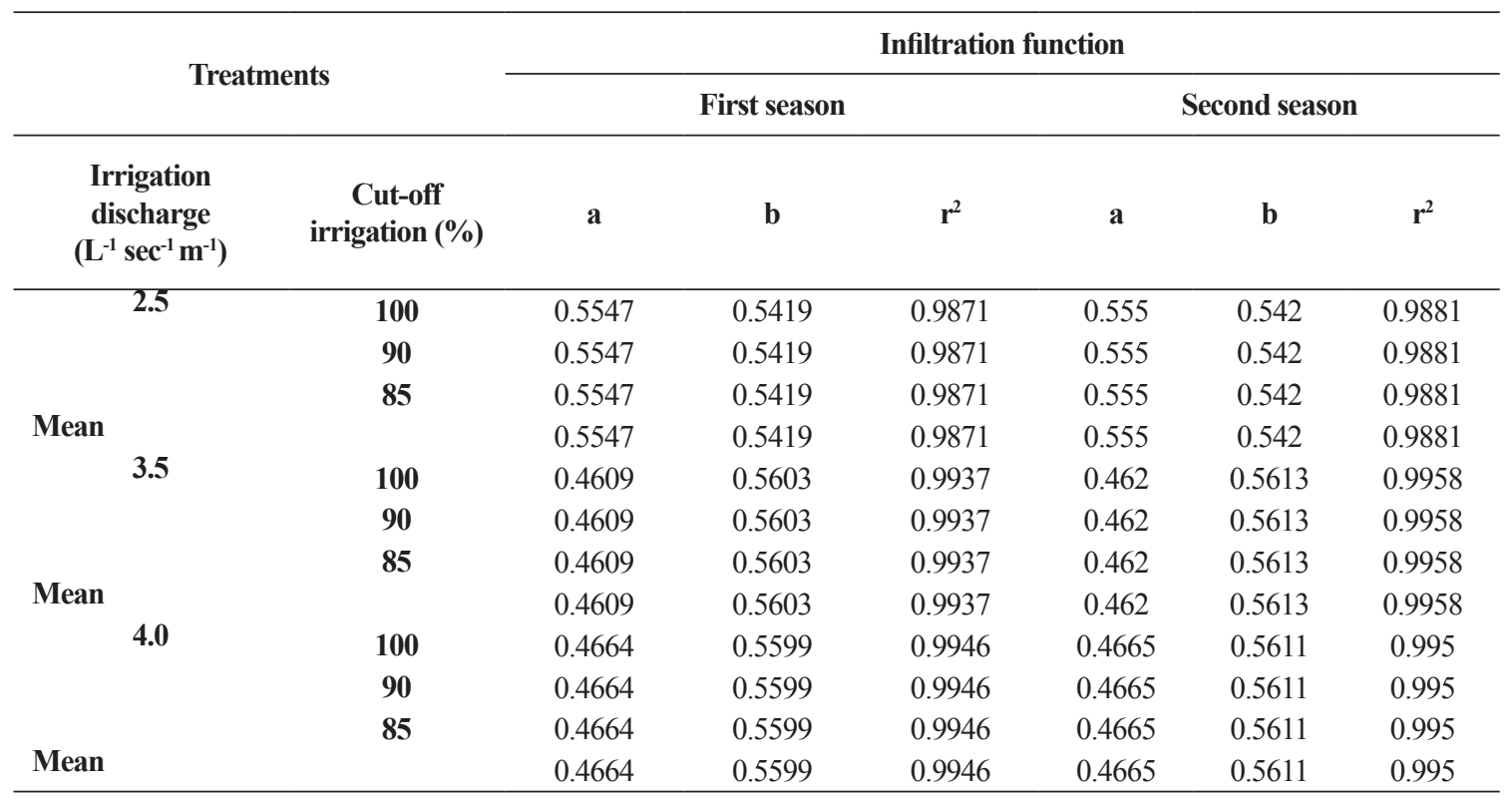

Egypt. J. Soil Sci., 58, No.2 (2018) 
This is the simple and well-known empirical infiltration function of the modifiedKostiakov equation (e.g., Walker, 2005 and Gillies and Smith, 2005) form, where $Z$ is the accumulated depth infiltrated $(\mathrm{cm}), \mathrm{t}$ is the elapsed time (minutes), and $\mathrm{a}\left(\mathrm{cm} / \mathrm{min}^{\mathrm{b}}\right)$ and $\mathrm{b}$ are regression coefficients. Available test data for post irrigation in both seasons were analyzed using a curve fitting regression. The results of individual regressions and averages for the different irrigation discharge and cut-off irrigation are given in Table 4. Average of all the tests conducted with the post irrigation in both seasons is considered representative of the soil intake conditions.

\section{Soil intake families}

The United States soil conservation service (SCS) has made a large number of field trails to measure and categorize infiltration rates. The SCS has used a slightly modified form of the Kostiakov equation to represent infiltration. Application of this method has been aided by use of the intake family concept.The governing equation for infiltration using the SCS method is given by :

$$
\mathrm{i}=\mathrm{a}(\mathrm{t})^{\mathrm{b}}+\mathrm{c}
$$

in which $\mathrm{i}$ and $\mathrm{t}$ are depth of infiltration, $\mathrm{cm}$ and time of infiltration, min and $\mathrm{a}$ and $\mathrm{b}$ are given as a function of intake family. A, which varies depending on whether $\mathrm{i}$ is determined in inches or centimeters, and $\mathrm{b}$ are listed for different intake families in Table (5).

With reference to the SCS procedures for level border (USDA,1974) and level furrow (USDA,1979) irrigation designs and the SCS methods for classifying soils into intake families, the following comments are made concerning the results in Table (6).

The results for the first season tests are considered representative of the soil infiltration characteristics at post irrigation in winter seasons. Intake rates were decreased from 8.88 to $0.89 \mathrm{~cm}$ $\mathrm{hr}^{-1}$, from 9.6 to $0.92 \mathrm{~cm} \mathrm{hr}^{-1}$ and from 9.84 to 0.93 $\mathrm{cm} \mathrm{hr}{ }^{-1}$ for $2.5,3.5$ and $4.0 \mathrm{~L} \mathrm{sec}^{-1} \mathrm{~m}^{-1}$ under all cut-off irrigation conditions.

This would be equivalent to $0.35,0.36$ and 0.37 intake families.

\section{Regression coefficient}

- The tests/conducted in the second season are considered representative of the post irrigation for winter season.

Generally, the average initial rates are 9.12, 9.72 and $10.1 \mathrm{~cm} \mathrm{hr}^{-1}$ for $2.5,3.5$ and $4 \mathrm{~L}^{-1} \mathrm{sec}^{-1}$ $\mathrm{m}^{-1}$ and decreased to $0.9,0.93$ and $0.94 \mathrm{~cm} \mathrm{hr}^{-1}$ at 240 minutes. These conditions are also roughly equivalent to the $0.35,0.37$ and 0.37 intake families.

TABLE 5. Intake family and advance coefficients for depth of infiltration in $\mathrm{mm}$, time in minutes and length in meters

\begin{tabular}{cccccc}
\hline Intake family & $\mathbf{a}$ & $\mathbf{b}$ & $\mathbf{c}$ & $\mathbf{f}$ & $\mathbf{g}$ \\
\hline 0.05 & 0.5334 & 0.618 & 7.0 & 7.16 & $1.088 \times 10^{-4}$ \\
0.1 & 0.6198 & 0.661 & 7.0 & 7.25 & $1.251 \times 10^{-4}$ \\
0.15 & 0.711 & 0.683 & 7.0 & 7.34 & $1.414 \times 10^{-4}$ \\
0.2 & 0.7772 & 0.699 & 7.0 & 7.43 & $1.578 \times 10^{-4}$ \\
0.25 & 0.8534 & 0.711 & 7.0 & 7.52 & $1.741 \times 10^{-4}$ \\
0.3 & 0.9246 & 0.72 & 7.0 & 7.61 & $1.904 \times 10^{-4}$ \\
0.35 & 0.9957 & 0.729 & 7.0 & 7.7 & $2.067 \times 10^{-4}$ \\
0.4 & 1.064 & 0.736 & 7.0 & 7.79 & $2.23 \times 10^{-4}$ \\
0.45 & 1.13 & 0.742 & 7.0 & 7.88 & $2.393 \times 10^{-4}$ \\
0.5 & 1.196 & 0.748 & 7.0 & 7.97 & $2.556 \times 10^{-4}$ \\
0.6 & 1.321 & 0.757 & 7.0 & 8.15 & $2.883 \times 10^{-4}$ \\
0.7 & 1.443 & 0.766 & 7.0 & 8.33 & $3.209 \times 10^{-4}$ \\
0.8 & 1.56 & 0.773 & 7.0 & 8.5 & $3.535 \times 10^{-4}$ \\
0.9 & 1.674 & 0.779 & 7.0 & 8.68 & $3.862 \times 10^{-4}$ \\
1.0 & 1.786 & 0.785 & 7.0 & 8.86 & $4.188 \times 10^{-4}$ \\
1.5 & 2.284 & 0.799 & 7.0 & 9.76 & $5.819 \times 10^{-4}$ \\
2.0 & 2.753 & 0.808 & 7.0 & 10.65 & $7.451 \times 10^{-4}$ \\
\hline
\end{tabular}

$\mathrm{Z}=\mathrm{a} \mathrm{T}^{\mathrm{b}}+\mathrm{c}$ where $\mathrm{Z}(\mathrm{mm})$ is intake depth, $\mathrm{T}(\mathrm{min})$ is intake opportunity time. 


\section{Uniformity coefficient of water applied}

The uniformity of water applied is a convenient way to judge the performance of irrigation methods. High values of water distribution uniformity meanthat different sections of the field received similar application depth.

As shown from Table 6 the results indicate the levels of uniformity. It is noted that calculated uniformity levels for the different irrigation water discharge and cut-off irrigation are higher in both seasons, usually more than 0.9 .

The uniformity coefficient values were 0.97 , 0.95 and 0.94 for $2.5,3.5$ and $4 \mathrm{~L} \mathrm{sec}^{-1} \mathrm{~m}^{-1}$ in the first season. While in the second season, the corresponding values were $0.96,0.95$ and 0.94 for the stated treatments. The highest values of distribution uniformity were obtained with cutoff irrigation at $90 \%$ of border length followed by $85 \%$ and $100 \%$ in the two growing seasons.

Generally, uniformity coefficient above 0.9 is considered suitable value, thus the designs formulated gave very acceptable levels of uniformity. The combined effects of different irrigation discharge and cut-off and precision land leveling plus the nature of the soil in the area contributed to the good results in Tables (5 and 6).

TABLE 6. Soil conservation service (SCS) intake family and application uniformity (Uch) for the different treatments for post irrigation in the 2 seasons

\begin{tabular}{|c|c|c|c|c|c|}
\hline \multicolumn{2}{|c|}{ Treatments } & \multicolumn{2}{|c|}{ First season } & \multicolumn{2}{|c|}{ Second season } \\
\hline $\begin{array}{l}\text { Irrigation discharge, } \\
\qquad \mathbf{L}^{-1} \sec ^{-1} \mathbf{m}^{-1}\end{array}$ & $\begin{array}{c}\text { Cut-off } \\
\text { irrigation, } \%\end{array}$ & $\begin{array}{c}\text { SCS } \\
\text { Intake family }\end{array}$ & $\begin{array}{c}\text { Application } \\
\text { uniformity }\end{array}$ & $\begin{array}{c}\text { SCS } \\
\text { Intake family }\end{array}$ & $\begin{array}{c}\text { Application } \\
\text { uniformity }\end{array}$ \\
\hline \multirow[t]{3}{*}{2.5} & 100 & 0.35 & 0.95 & 0.35 & 0.94 \\
\hline & 90 & 0.35 & 0.98 & 0.35 & 0.98 \\
\hline & 85 & 0.35 & 0.97 & 0.35 & 0.97 \\
\hline \multicolumn{2}{|c|}{ Mean } & 0.35 & 0.97 & 0.35 & 0.96 \\
\hline \multirow[t]{4}{*}{3.5} & 100 & 0.36 & 0.92 & 0.37 & 0.92 \\
\hline & 90 & 0.36 & 0.97 & 0.37 & 0.97 \\
\hline & 85 & 0.36 & 0.95 & 0.37 & 0.95 \\
\hline & & 0.36 & 0.95 & 0.37 & 0.95 \\
\hline \multirow[t]{3}{*}{4.0} & 100 & 0.37 & 0.91 & 0.37 & 0.92 \\
\hline & 90 & 0.37 & 0.96 & 0.37 & 0.96 \\
\hline & 85 & 0.37 & 0.95 & 0.37 & 0.95 \\
\hline \multicolumn{2}{|c|}{ Mean } & 0.37 & 0.94 & 0.37 & 0.94 \\
\hline
\end{tabular}

\section{Effects of design parameters variation}

An irrigation system is usually designed to supply the crop water requirements during some peak use period. Typically, such a design may be based on the design conditions ,i.e. design parameter values at the time of the peak use period. The variation over time of the design parameters is an important consideration which is often neglected. The designer must be aware of the effects of design parameter variation on system performance to formulate an effective design and to develop appropriate system management recommendations.

The purpose here is to discuss generally, the effects of different water discharge and cutoff time and soil intake family on irrigation performances for dealing with those changes.
For level border design the analysis was for the effects of changing the water discharge and cutoff irrigations. The results showed that under conditions of irrigation discharge $4 \mathrm{~L} \mathrm{sec}^{-1} \mathrm{~m}^{-1}$ combined with cut-off at $85 \%$ of border length, the designed inflow time, deep percolation and run-off values were decreased, while water application efficiency were increased. Also, lower discharge with all conditions of cut-off gives lower application efficiency.It is noted that when the calculated application time of $231 \mathrm{~min}$. is reduced to just $223 \mathrm{~min}$. then the depth applied increased from 115.6 to $117.2 \mathrm{~mm}$, the application efficiency goes to $97.3 \%$. Table 8 declares the ratio of inflow time to advance time. This ratio is more than 2, meanwhile, the application time increased over the advance time, in this case the design is acceptable in clay soil.

Egypt. J. Soil Sci., 58, No.2 (2018) 
Design evaluation: A case study

Season of 2013/2014: Evaluating selected design parameters

A wide range of design border strip dimensions was tried for the various design conditions in Sakha site during the investigation. Post irrigation evaluations were conducted for the different treatments including different irrigation discharge and cut-off irrigation to evaluate the designs and to determine if the assumptions used in formulating the designs were correct. The design conditions for each treatment are compared with the measured conditions of the post irrigation. Where available, advance and recession data are used in this analysis.

These data were generally collected for each $10-\mathrm{m}$ interval of strip length. Often the recession was uniform enough that the entire field was considered to have completed this phase. Tables 7 and 8 are a comparison of the design conditions and measured conditions for each treatment for the post irrigation. The design and measured data include comparison between unit width inflow rate, maximum unit width inflow rate, minimum unit width inflow rate, advance time, advance ratio, net irrigation water applied, gross irrigation water applied, run-off, deep percolation and water application efficiency.

From the result in Tables (7 - 9) and Figures (3 - 8) it can be noted that:

- The measured irrigation stream was more than the design irrigation stream. These factors caused increasing the amount of water applied

- It is seen that, advance time, recession time and opportunity time were more than the measured one.

- The distribution of applied water was good.

- The combination of existing factors produced a relatively efficient irrigation.

- It can be concluded that the highest values of designed and measured water application efficiency was achieved from the combination between irrigation discharge at $4 \mathrm{~L} \mathrm{sec}^{-1} \mathrm{~m}^{-1}$ and cut-off at $85 \%$ from border length

- It can be concluded that the design is reasonably efficient

- The design values for different parameters fall within all the design limitations.

TABLE 7. Comparison of design and measured unit width inflow rate for level border strips at Sakha farm, post irrigation

\begin{tabular}{|c|c|c|c|c|c|c|c|c|c|}
\hline \multicolumn{2}{|c|}{ Treatments } & \multicolumn{2}{|c|}{$\begin{array}{l}\text { Strip design } \\
\text { dimensions* }\end{array}$} & \multicolumn{2}{|c|}{$\begin{array}{l}\text { Unit width inflow } \\
\text { rate } \mathrm{LPS} / \mathrm{m}\end{array}$} & \multicolumn{2}{|c|}{$\begin{array}{l}\text { Maximum unit width in } \\
\text { flow rate }\left(\mathrm{m}^{2} / \mathrm{sec}\right)\end{array}$} & \multicolumn{2}{|c|}{$\begin{array}{l}\text { Minimum unit width } \\
\text { in flow rate }\left(\mathrm{m}^{2} / \mathrm{sec}\right)\end{array}$} \\
\hline 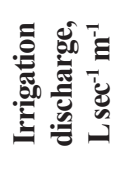 & U气 & 氖 & 䒿 & 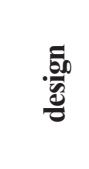 & 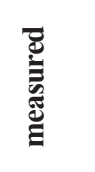 & 预 & 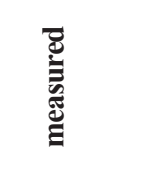 & 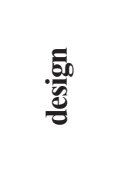 & 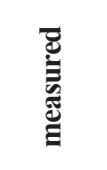 \\
\hline \multirow{3}{*}{2.5} & 100 & $5-18$ & 240 & 1.4 & 2.5 & 0.03139 & 0.0025 & 0.0003 & 0.0025 \\
\hline & 90 & $5-18$ & 216 & 1.29 & 2.5 & 0.03139 & 0.0025 & 0.00027 & 0.0025 \\
\hline & 85 & $5-18$ & 204 & 1.25 & 2.5 & 0.03139 & 0.0025 & 0.00026 & 0.0025 \\
\hline \multirow{3}{*}{3.5} & 100 & $5-18$ & 240 & 1.40 & 3.5 & 0.03139 & 0.0035 & 0.0003 & 0.0035 \\
\hline & 90 & $5-18$ & 216 & 1.29 & 3.5 & 0.03139 & 0.0035 & 0.00027 & 0.0035 \\
\hline & 85 & $5-18$ & 204 & 1.25 & 3.5 & 0.03139 & 0.0035 & 0.00026 & 0.0035 \\
\hline \multirow{3}{*}{4.0} & 100 & $5-18$ & 240 & 1.40 & 4.0 & 0.03139 & 0.004 & 0.0003 & 0.004 \\
\hline & 90 & $5-18$ & 216 & 1.29 & 4.0 & 0.03139 & 0.004 & 0.00027 & 0.004 \\
\hline & 85 & $5-18$ & 204 & 1.25 & 4.0 & 0.03139 & 0.004 & 0.00026 & 0.004 \\
\hline
\end{tabular}

*Booher, 1974. 
TABLE 8. Comparison of measured and design of advance, recession, opportunity and cut-off time for level border strips at Sakha farm (post irrigation) 2013/2014

\begin{tabular}{|c|c|c|c|c|c|c|c|c|c|c|c|c|c|c|c|}
\hline \multicolumn{2}{|c|}{ Treatments } & \multirow{2}{*}{ 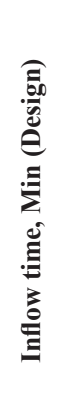 } & \multirow{2}{*}{ 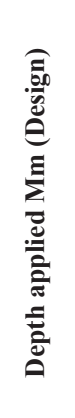 } & \multirow{2}{*}{ 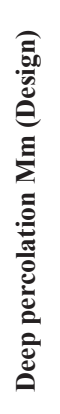 } & \multirow{2}{*}{ 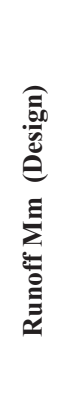 } & \multirow{2}{*}{ 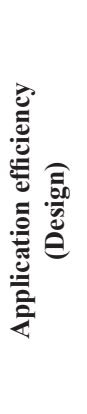 } & \multirow{2}{*}{ 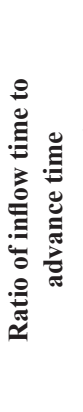 } & \multicolumn{2}{|c|}{$\begin{array}{c}\text { Advance } \\
\text { time } \\
\text { (min.) }\end{array}$} & \multicolumn{2}{|c|}{$\begin{array}{c}\text { Recession } \\
\text { time } \\
(\min .)\end{array}$} & \multicolumn{2}{|c|}{$\begin{array}{c}\text { Opportunity } \\
\text { time } \\
\text { (min.) }\end{array}$} & \multicolumn{2}{|c|}{$\begin{array}{c}\text { Cut-off } \\
\text { time } \\
\text { (min.) }\end{array}$} \\
\hline 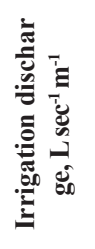 & 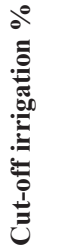 & & & & & & & 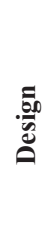 & 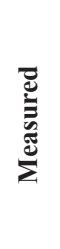 & 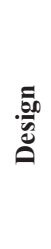 & 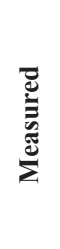 & 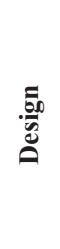 & 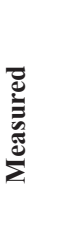 & 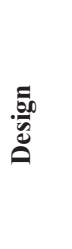 & 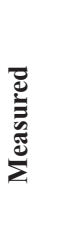 \\
\hline \multirow{4}{*}{2.5} & 100 & 231 & 115.6 & 6.8 & 44.77 & 94.12 & 2.42 & 95 & 90 & 114 & 108 & 301 & 151 & 288 & 135 \\
\hline & 90 & 231 & 115.6 & 6.8 & 44.77 & 94.12 & 2.7 & 85 & 100 & 104 & 98 & 301 & 151 & 289 & 135 \\
\hline & 85 & 231 & 115.6 & 6.8 & 44.77 & 94.12 & 2.89 & 80 & 104 & 99 & 93 & 301 & 150 & 289 & 134 \\
\hline & 100 & 225 & 115.8 & 5.0 & 43.19 & 95.7 & 2.36 & 95 & 62 & 114 & 108 & 301 & 158 & 288 & 141 \\
\hline \multirow[t]{3}{*}{3.5} & 90 & 225 & 115.8 & 5.0 & 43.19 & 95.7 & 2.63 & 85 & 75 & 104 & 98 & 301 & 158 & 289 & 141 \\
\hline & 85 & 225 & 115.8 & 5.0 & 43.19 & 95.7 & 2.82 & 80 & 79 & 99 & 93 & 301 & 158 & 289 & 141 \\
\hline & 100 & 223 & 117.2 & 3.2 & 42.77 & 97.27 & 2.34 & 95 & 53 & 114 & 108 & 301 & 154 & 288 & 136 \\
\hline \multirow[t]{2}{*}{4.0} & 90 & 223 & 117.2 & 3.2 & 42.77 & 97.27 & 2.61 & 85 & 63 & 104 & 98 & 301 & 153 & 289 & 135 \\
\hline & 85 & 223 & 117.2 & 3.2 & 42.77 & 97.27 & 2.79 & 80 & 66 & 99 & 93 & 301 & 153 & 289 & 135 \\
\hline
\end{tabular}

The border length was taken from Booher (1974).

TABLE 9. Comparison of design and measured advance ratio, net irrigation water applied, gross irrigation water applied, run-off, deep percolation and water application efficiency (post irrigation)

\begin{tabular}{|c|c|c|c|c|c|c|c|c|c|c|c|c|c|}
\hline \multicolumn{2}{|c|}{ Treatments } & \multicolumn{2}{|c|}{$\begin{array}{c}\text { Advance ratio } \\
\text { (advance time/ } \\
\text { opportunity) }\end{array}$} & \multicolumn{2}{|c|}{$\begin{array}{l}\text { net irrigation } \\
\text { water applied } \\
\quad(\mathrm{mm})\end{array}$} & \multicolumn{2}{|c|}{$\begin{array}{c}\text { gross irrigation } \\
\text { water applied } \\
(\mathrm{mm})\end{array}$} & \multicolumn{2}{|c|}{ run-off (mm) } & \multicolumn{2}{|c|}{$\begin{array}{c}\text { deep } \\
\text { percolation } \\
(\mathrm{mm})\end{array}$} & \multicolumn{2}{|c|}{$\begin{array}{c}\text { water } \\
\text { application } \\
\text { efficiency, \% }\end{array}$} \\
\hline 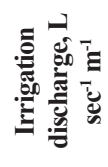 & 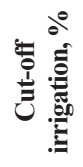 & 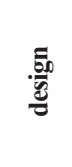 & 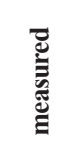 & 鸹 & 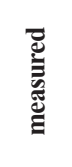 & : & 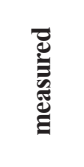 & 昜 & 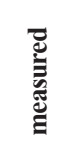 & $\frac{5000}{8}$ & 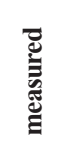 & 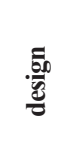 & 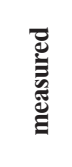 \\
\hline \multirow[t]{3}{*}{2.5} & 100 & 0.32 & 0.60 & 77.6 & 77.2 & 115.6 & 135.0 & 44.8 & 51.9 & 0.2 & 6.8 & 87.5 & 57.19 \\
\hline & 90 & 0.28 & 0.66 & 77.6 & 77.2 & 115.8 & 126.0 & 43.2 & 42.0 & 0.2 & 5.0 & 89.6 & 61.27 \\
\hline & 85 & 0.26 & 0.69 & 77.6 & 77.2 & 117.2 & 120.0 & 42.8 & 36.3 & 0.2 & 3.2 & 90.7 & 64.33 \\
\hline \multirow{3}{*}{3.5} & 100 & 0.32 & 0.39 & 77.6 & 77.2 & 115.6 & 130.2 & 44.8 & 51.5 & 0.2 & 6.8 & 87.5 & 59.3 \\
\hline & 90 & 0.28 & 0.47 & 77.6 & 77.2 & 115.8 & 121.8 & 43.2 & 43.2 & 0.2 & 5.0 & 89.6 & 63.38 \\
\hline & 85 & 0.26 & 0.5 & 77.6 & 77.2 & 117.2 & 117.6 & 42.8 & 39.1 & 0.2 & 3.2 & 90.7 & 65.65 \\
\hline \multirow[t]{3}{*}{4.0} & 100 & 0.32 & 0.34 & 77.6 & 77.2 & 115.6 & 127.2 & 44.8 & 49.0 & 0.2 & 6.8 & 87.5 & 60.69 \\
\hline & 90 & 0.28 & 0.41 & 77.6 & 77.2 & 115.8 & 112.8 & 43.2 & 34.8 & 0.2 & 5.0 & 89.6 & 68.44 \\
\hline & 85 & 0.26 & 0.43 & 77.6 & 77.2 & 117.2 & 108.0 & 42.8 & 30.0 & 0.2 & 3.2 & 90.7 & 71.48 \\
\hline
\end{tabular}

Egypt. J. Soil Sci., 58, No.2 (2018) 


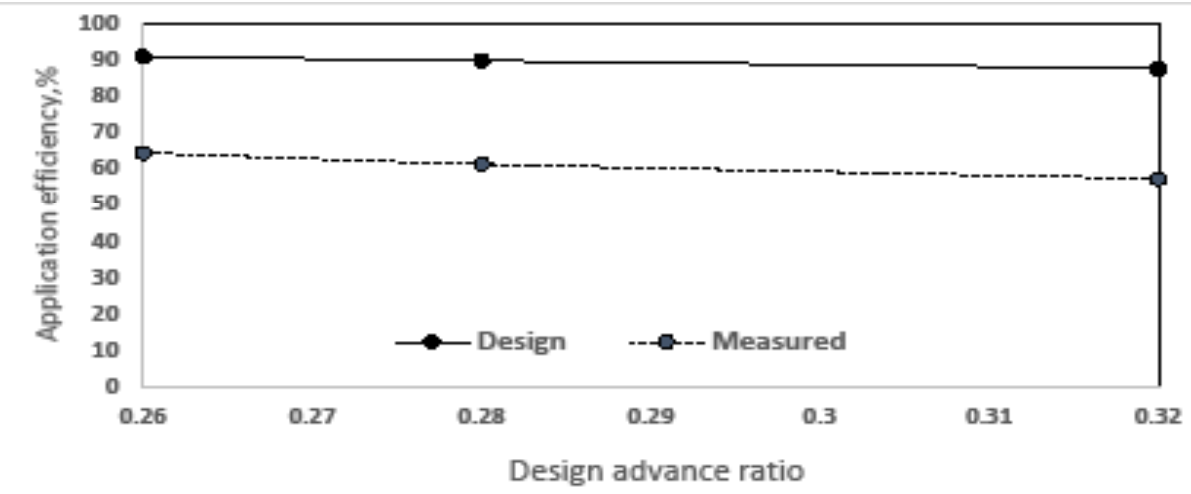

Fig. 3. Relation between design advance ratio and application efficiency, $\%$ for design and measured under irrigation discharge of $2.5 \mathrm{~L} \mathrm{sec}^{-1} \mathrm{~m}^{-1}$ (post irrigation )

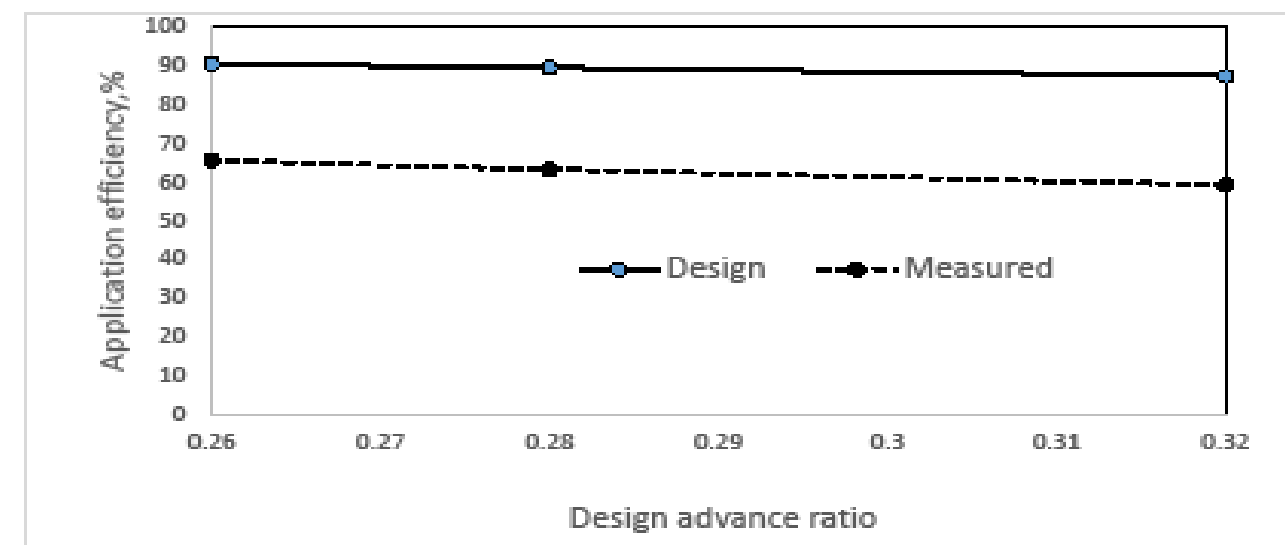

Fig. 4. Relation between design advance ratio and application efficiency, \% for design and measured under irrigation discharge of $3.5 \mathrm{~L} \mathrm{sec}^{-1} \mathrm{~m}^{-1}$ (post irrigation )

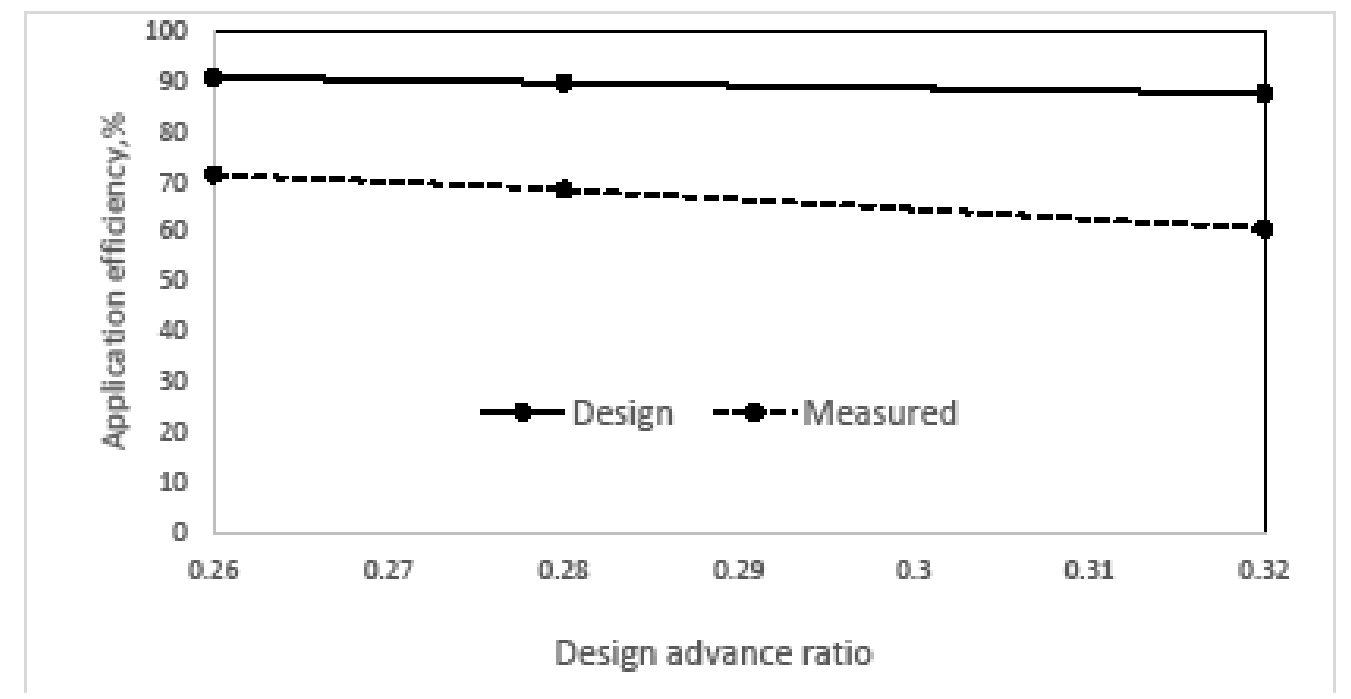

Fig. 5. Relation between design advance ratio and application efficiency, \% for design and measured under irrigation discharge of $4 \mathrm{~L} \mathrm{sec}^{-1} \mathrm{~m}^{-1}$ (post irrigation ) 


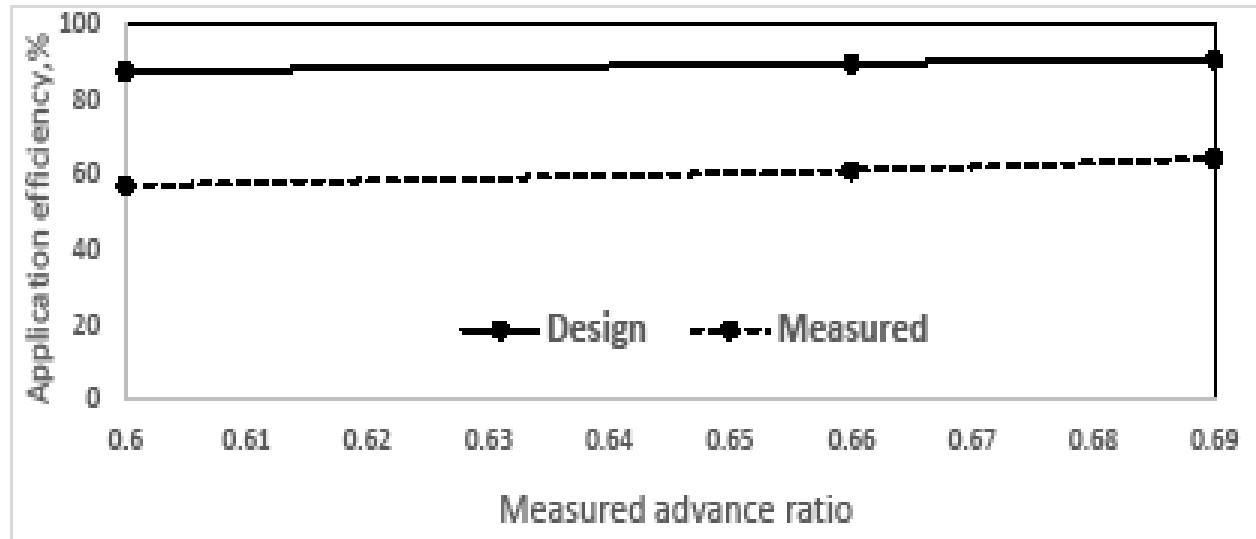

Fig. 6. Relation between measured advance ratio and application efficiency, $\%$ for design and measured under irrigation discharge of $2.5 \mathrm{~L} \mathrm{sec}^{-1} \mathrm{~m}^{-1}$ (post irrigation )

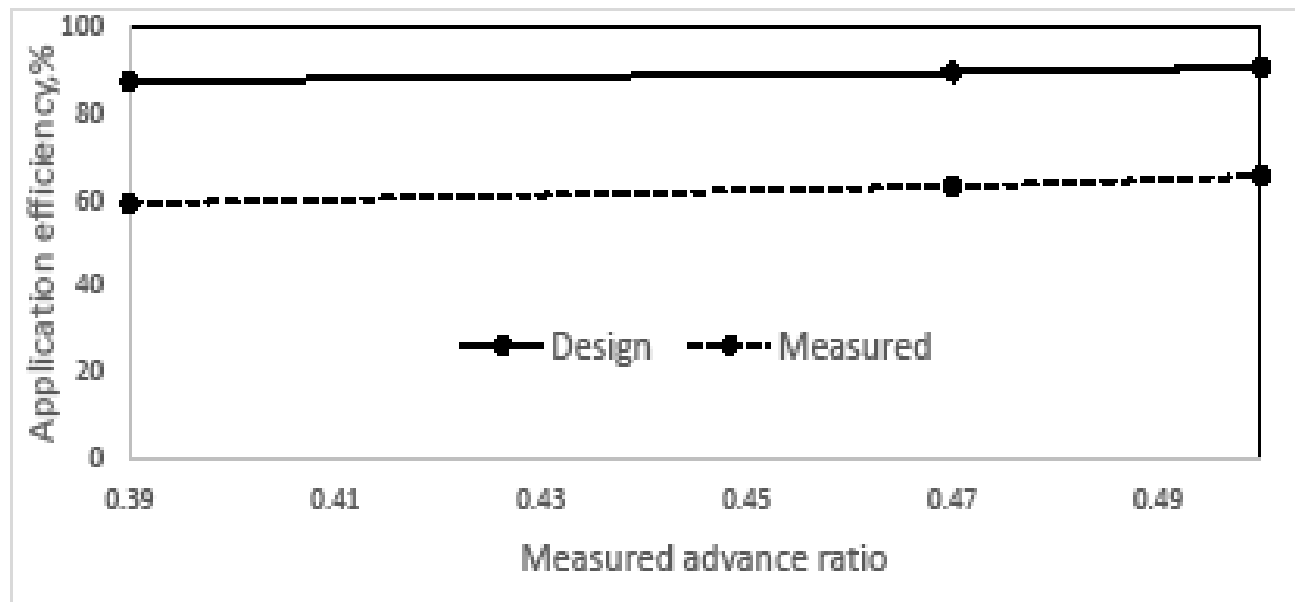

Fig. 7. Relation between measured advance ratio and application efficiency, $\%$ for design and measured under irrigation discharge of $3.5 \mathrm{~L} \mathrm{sec}^{-1} \mathrm{~m}^{-1}$ (post irrigation )

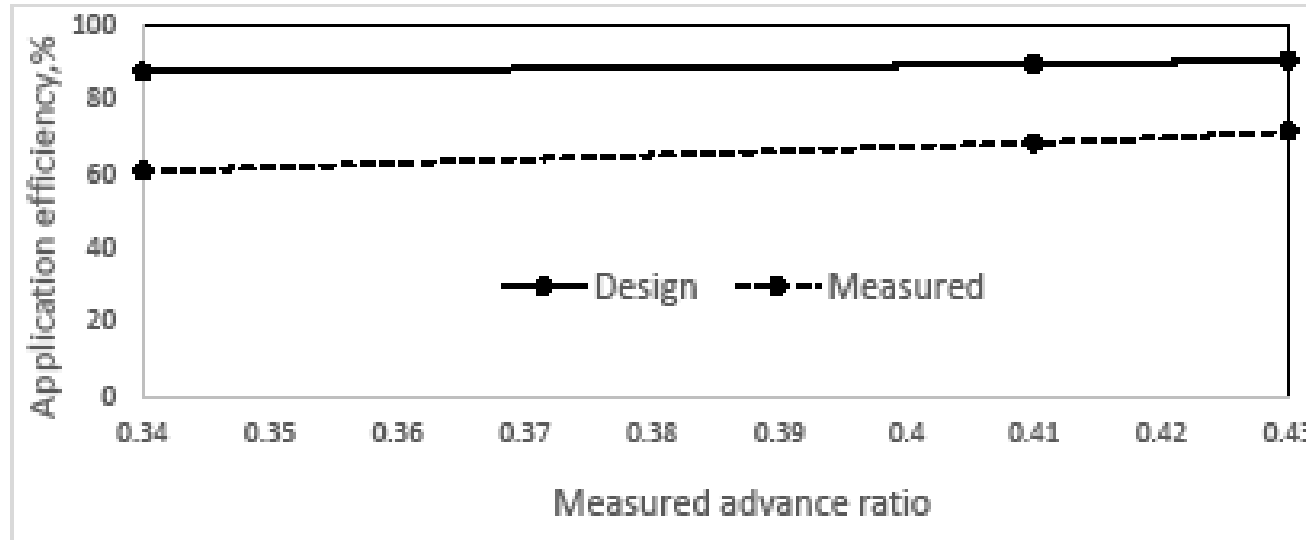

Fig. 8. Relation between measured advance ratio and application efficiency, $\%$ for design and measured under irrigation discharge of $4 \mathrm{~L} \mathrm{sec}^{-1} \mathrm{~m}^{-1}$ (post irrigation ) 


\section{Conclusion}

For level border design, the analysis was for the effects of changing the water discharge and cut-off irrigations. The results indicated that under conditions of $4 \mathrm{~L}$ sec- $1 \mathrm{~m}-1$ irrigation discharge combined with cut-off at $85 \%$ of border length, the designed inflow time, deep percolation and run-off were decreased, while water with all conditions of cut-off which gives lower application efficiency were increased. On the other hand lower water discharge application efficiency. It can be concluded that the design of the border irrigation is reasonably efficient and fall within all the design limitations.

\section{References}

Amer, A.M. (2011) Evaluation of surface irrigation as a function of water infiltration in cultivated soils in the Nile Delta. Irrig. Drainage System. 25, 367-383.

Anwar, A.A.; Ahmad, W., Bhatti, M.T. and UlHag, Z. (2016) The potential of precision surface irrigation in the Indus Basin Irrigation System. Irrig. Sci. 34, 379-396.

Aragues,R., Urdanoz., V., Cetin, M., Kirda; C., Daghari, H., Ltifi, W., Lahlou, M. and Douaik, A. (2011) Soil salinity related to physical soil characteristics and irrigation management in four Mediterranean irrigation districts. Agricultural water management. 98 (6), 959-966.

Bautista E., Clemmens, A. J., Strelkossand, T. S., Niblack,M. (2009) Analysis of surface irrigation systems with Win SRFR-example application. Agric. Water Manag. 96, 1162-1169.

Booher, L.J. (1974) Surface Irrigation.FAO Agricultural Development .paper, No.95.Withers, B and Viprads.

Campbell, D.J. (1994) Determination and use of bulk density in relation to soil compaction.In Soane and Ouwerk (Ed.).Soil Compaction in Crop Production. Elsevier, London and Amsterdam.

Chen, B., Ouyang, Z., Sun, Z., Wu, L. and Li, F. (2012) Evaluation on the potential of improving border irrigation performance through border dimensions optimization: a case study on the irrigation districts along the lower Yellow River. Irrig. Sci. 31, 715728.

Darouich, H., Jose M. Goncalves, Andre Muga and Luis S. Pereira (2012) Water savings Vs. farm economic in cotton surface irrigation: An application of multi criteria analysis. Agric. Water Manag. 115, 223-231.
EL-Hadidi, E. M., Saied, M.M., Ghaly, Fatma M. and Khalifa, R. M. (2016) Assessing the effect of water discharge rates and cut-off irrigation on wheat production and some water relations at North Nile Delta Region. J. Soil Sci. and Agric. Eng., Mansoura Univ., 7 (6), 397-407.

Garcia, I. (1978) Soil Water Engineering Laboratory Manual.Agric. and Chem. Eng. Dept., Colorado State Univ., fort. Collins, USA.

Gillies, M. H. and Smith, R.J. (2005) Infiltration parameters from surface irrigation advance and run-off data. Irrig. Sci., 24 (1), 25-35.

Klute, A. (1986) Methods of Soil Analysis. Part1. Physical and Mineralogical Methods. $2^{\text {nd }}$ ed. Amer. Soc. of Agron. Inc. Madison, Wisconsin, USA.

Miao Q., Shi, H, Goncalves,J M. and Pereira, L S (2015) Field assessment of basin irrigation performance and water saving in Hetao, Yellow River basin: Issues to support irrigation systems modernisation. Bio-systems Engineering J., 136, 100-116.

Mohamedin, A.A.M., Awaad, M.S. and Ahmed, A.R. (2010) The negative role of salinity and waterlogging on crop productivity in the northeastern region of the Nile Delta, Egypt. Research Journal of Agriculture and Biological Sciences, 6 (4), 378-385.

Morris, M.R., Hussian, A., Gillies, M.H. and O'Halloran, N.J. (2015) Inflow rate and border irrigation performance. Agric. Water Manag. 155, 76-86.

Page, A. L., Miller, R.H. and Keeney, D.R. (1982) Methods of Soil Analysis.Part 2.Chemical and Microbiological Properties. $2^{\text {nd }}$ (Ed.). Amer. Soc. of Agron., Madison, Wisconsin, U.S.A.

Pereira, L. S., Cordery, L. and Lacovides, I. (2012) Improved indicators of water use performance and productivity for sustainable water conservation and saving. Agric. Water Manag. 108, 39-51.

Richard, H.C. (1989) Irrigation System Design. An Engineering Approach..Library of Congress Cataloging in publication Data.

Salahou, M.K., Jiao, X. and Haishen, Lu (2018) Border irrigation performance with distance-based cut-off. Agric. Water Manag. 201, 27-37.

Strelkoff, T.S., Clemmens,A. J., EL-Ansary, M. and Awad, M, (1999) Surface irrigation evaluation models; Application to level basins in Egypt. 42 (4), 1027-1036, Transactions of ASAE, 1999 American 
Society of Agricultural Engineers.

U. S. Department of Agriculture (1974) Border irrigation. National Engineering Handbook, chapter 4, section 15, SCS, U.S. Government printing office, Washington, D.C.

U. S. Department of Agriculture. (1979) Furrow Irrigation. National Engineering Handbook, chapter5, section 15, SCS, U. S. Government Printing Office, Washington D.C. infiltration and roughness. J. Irrigation Drainage Eng. 131 (2), 129-135.

Zerihun, D., Sanchez, C. A.,. Farrell-poe, K. L. and Yitayew, M. (2005) Analysis and Design of border irrigation systems. Transactions of the ASAE. 48, 1751-1764. Am. Soc. Agric. Eng. ISSN 000123511751 .

(Received:28/1/2018; accepted:19/4/2018)

Walker, W. R. (2005) Multi-level calibration of furrow

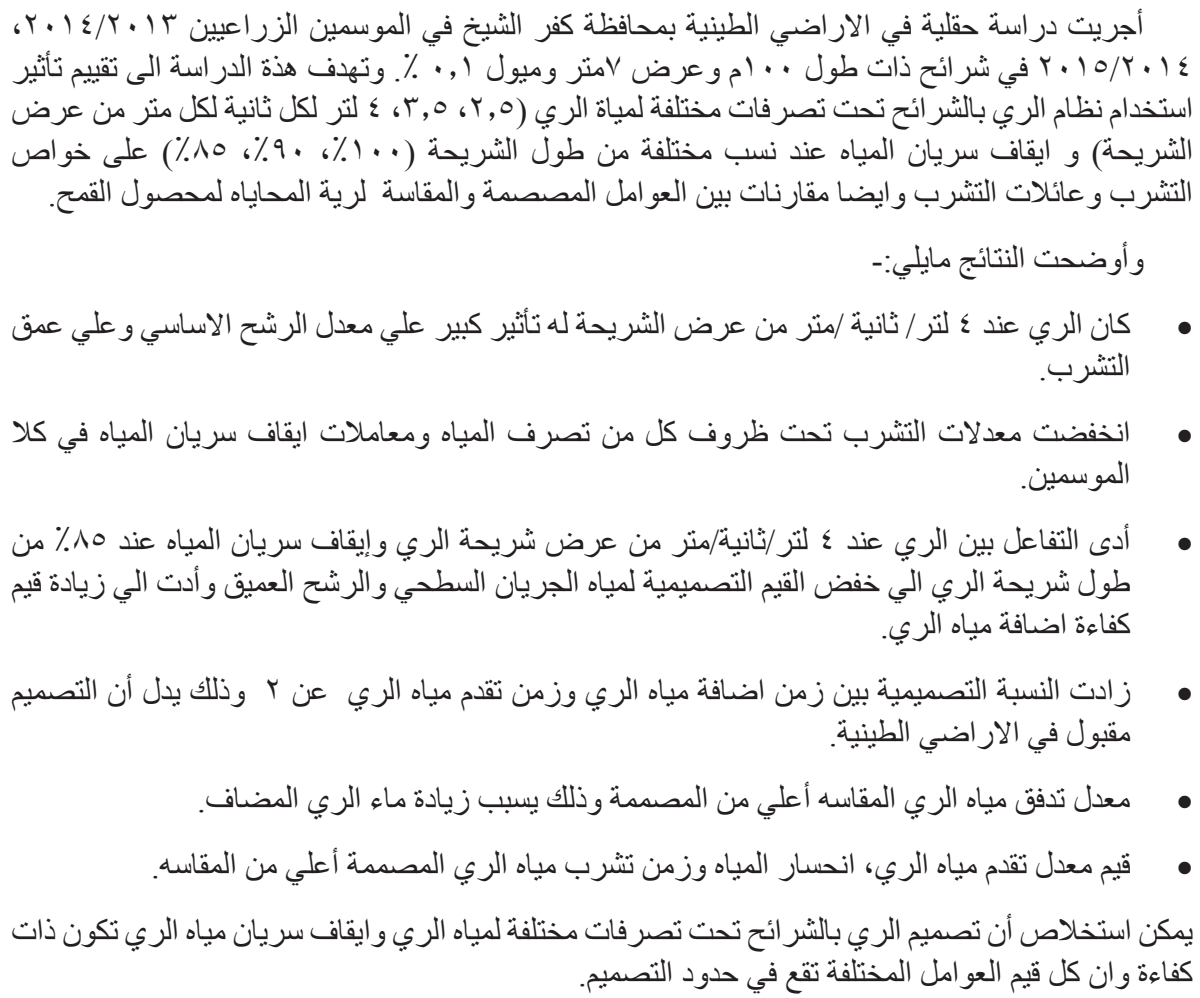

